Check for updates

The BMJ

kabbasi@bmi.com Follow Kamran on Twitter@KamranAbbasi

Cite this as: $B M / 2020 ; 369: m 2432$ http://dx.doi.org/10.1136/bmj.m2432 Published: 18 June 2020

\section{Rashford, racism, and bankrupt excuses}

\section{Kamran Abbasi executive editor}

In a week when rioting protesters gave "football lads" a bad name, a lad who merely plays football for Manchester United showed that our priorities should be focused on protecting the nation's vulnerable children. Marcus Rashford grew up relying on free school meals. He reached beyond politics to a common humanity, but his appeal to the UK government to extend its current scheme through the school holidays was at first dismissed.

Rashford has science on his side. Ian Sinha and colleagues include the rising tide of food insecurity in their list of ways in which children's health and wellbeing are being sidelined by covid-19. ${ }^{1}$ The long term harm of poor health in childhood is well established, and a policy focus is urgently needed, they say.

In $201730 \%$ of English children lived in poverty. The United Nations damned this as a social calamity and economic disaster. In times of hardship, such as austerity or a pandemic crisis, disadvantaged children are worst affected. This is not a case of individual responsibility. Children don't choose the poverty they are born into and live with, or the parental circumstances that lead to them being unvaccinated, unfed, or brought up on junk food. ${ }^{23}$

The incidence of covid-19 is low in children, but evidence grows of a rare, multisystem inflammatory syndrome related to Kawasaki disease. ${ }^{4}$ The illness is severe and disproportionately affects black children, although outcomes are favourable with intensive hospital care. As with much of the clinical management of covid-19, our understanding remains limited, and early guidelines had methodological weaknesses. ${ }^{5}$ One route through the fog is to remain rooted in sound clinical practice. A thorough history is helpful in disentangling an asthma exacerbation from covid-19, for example. ${ }^{6}$

Sound data help too. The ISARIC study of 20000 hospital inpatients clarifies the comorbidities that lead to hospital admission. ${ }^{7}$ But our ability to understand the high impact of covid-19 on ethnic minority patients and staff continues to be hampered by absent, limited, and poor quality data. This is a decades old scandal. We are at last seeing progress from the people shaping the new NHS Race and Health Observatory. ${ }^{8}$ Publication of an inexplicably delayed but straightforward Public Health England report on covid-19 and ethnic minorities will contribute. $^{9}$

Sound beats soundbite, though. The UK RECOVERY trial announced that dexamethasone may reduce deaths in people requiring respiratory support for covid-19 but didn't back its claims with a published research paper or preprint. ${ }^{10}$ This is how good news becomes suspect, how worthwhile endeavour is reduced to click-bait soundbite. There is no excuse to justify not feeding hungry children. There is no excuse for dither and delay on tackling racism and ethnic disparities. There is no excuse for press releasing the results of a major therapeutic trial without opening up your methods for scrutiny. The post-covid world must be one without bankrupt excuses.

Sinha I, Bennett D, Taylor-Robinson DC Children are being sidelined by covid-19. BMJ 2020;369:m2061. https://www.bmj.com/content/369/bmi.m2061. doi: 10.1136/bmi.m2061 pmid: 32461203

2 Megget K. Even covid-19 can't kill the anti-vaccination movement. BMJ 2020·369-m2184 https//www bmi.com/content/369/bmi.m2184. doi: 10.1136/bmj.m2184 pmid: 32499217

3 Tan M, He FJ, MacGregor GA. Obesity and covid-19: the role of the food industry. BMJ2020;369:m2237. https://www.bmj.com/content/369/bmj.m2237. doi: 10.1136/bmj.m2237 pmid: 32522740

4 Toubiana J, Poirault C, Corsia A, etal. Kawasaki-like multisystem inflammatory syndrome in children during the covid-19 pandemic in Paris, France: prospective observational study. BMJ2020;369:m2094 https://www.bmj.com/content/369/bmj.m2094. doi: 10.1136/bmi.m2094 pmid: 32493739

5 Dagens A, Sigfrid L, Cai E, etal. Scope, quality, and inclusivity of clinical guidelines produced early in the covid-19 pandemic: rapid review. BMJ 2020;369:m1936. https://www.bmj.com/content/369/bmj.m1936. doi: 10.1136/bmi.m1936 pmid: 32457027

6 Beaney T, Salman D, Samee T, Mak V. Assessment and management of adults with asthma during the covid-19 pandemic. BMJ2020;369:m2092 https://www.bmi.com/content/369/bmi.m2092 doi: 10.1136/bmj.m2092 pmid: 32513811

7 Docherty AB, Harrison EM, Green CA, etallSARIC4C investigators. Features of 20133 UK patients in hospital with covid-19 using the ISARIC WHO Clinical Characterisation Protocol: prospective observational cohort study. BMJ 2020;369:m1985. https://www.bmj.com/content/369/bmj.m1985. doi: 10.1136/bmj.m1985 pmid: 32444460

8 Kmietowicz Z. New observatory will set out actions to tackle racism "within months," say campaigners. BMJ 2020;369:m2395. https://www.bmi.com/content/369/bmi.m2395. doi: 10.1136/bmj.m2395 pmid: 32540849

9 lacobucci G. Covid-19: Racism may be linked to ethnic minorities' raised death risk, says PHE. BMJ2020;369:m2421. https://www.bmj.com/content/369/bmi.m2421.

10 Mahase E. Covid-19: Low dose steroid cuts death in ventilated patients by one third, trial finds. BMJ2020;369:m2422. https://www.bmi.com/content/369/bmi.m2422.

This article is made freely available for use in accordance with BMJ's website terms and conditions for the duration of the covid-19 pandemic or until otherwise determined by BMJ. You may use download and print the article for any lawful, non-commercial purpose (including text and data mining) provided that all copyright notices and trade marks are retained. 